\title{
Differential regulation of insulin-like growth factor binding protein- $I$ and -2 by insulin in the baboon (Papio anubis) endometrium
}

\author{
Steven D Fleming ${ }^{1}$, Asgerally T Fazleabas*2 and Stephen C Bell ${ }^{3}$
}

Address: ${ }^{1}$ Department of Obstetrics and Gynaecology, University of Sydney, NSW 2145, Australia, ${ }^{2}$ Department of Obstetrics and Gynecology (MC808), College of Medicine, University of Illinois at Chicago, Illinois 60612-9998, USA and ${ }^{3}$ Department of Obstetrics and Gynaecology, University of Leicester, Leicestershire LE2 7LE, UK

Email: Steven D Fleming - stevenf@westgate.wh.usyd.edu.au; Asgerally T Fazleabas* - asgi@uic.edu; Stephen C Bell - scb@leicester.ac.uk

* Corresponding author

Published: 3I January 2008

Reproductive Biology and Endocrinology 2008, 6:6 doi:10.1 186/1477-7827-6-6

This article is available from: http://www.rbej.com/content/6/1/6

(c) 2008 Fleming et al; licensee BioMed Central Ltd.

This is an Open Access article distributed under the terms of the Creative Commons Attribution License (http://creativecommons.org/licenses/by/2.0), which permits unrestricted use, distribution, and reproduction in any medium, provided the original work is properly cited.
Received: 20 August 2007

Accepted: 31 January 2008

\begin{abstract}
Background: The purpose of this study was to examine the effect of insulin on expression and synthesis of IGFBP-I and IGFBP-2 in the baboon endometrium in vitro.

Methods: Baboon endometrial explants collected from cycling, ovariectomized, steroid-treated, simulated-pregnant and pregnant animals were cultured for $48 \mathrm{~h}$ in the presence or absence of insulin, with or without estradiol, progesterone and hCG.

Results: Insulin clearly inhibited IGFBP-I production and mRNA expression in a time- and dosedependent manner, whereas IGFBP-2 synthesis was not significantly affected. The inhibitory effects of insulin on IGFBP-I were more evident in explants of non-pregnant tissue or tissue away from the implantation site. In the absence of insulin, synthesis of IGFBP-I was induced in explants with low levels of de novo synthesis whereas IGFBP-2 synthesis was inhibited. This effect was potentiated by steroids and hCG in the explant cultures.
\end{abstract}

Conclusion: Insulin differentially regulates endometrial IGFBP-I and IGFBP-2 secretion in the baboon.

\section{Background}

The insulin-like growth factor binding proteins (IGFBPs) include IGFBP-1 and IGFBP-2 that are non-glycosylated, low molecular weight IGFBPs that have a homologous amino acid sequence. They are important modulators of insulin-like growth factor (IGF) bioactivity. In this respect, IGFBP-1 and IGFBP-2 may potentiate the binding of IGFs to target cells via integrin receptors by virtue of the fact that both IGFBP-1 and IGFBP-2 have Arg-Gly-Asp (RGD) sequences at their C-terminus. The IGFs, IGF-1 and IGF-2, are mitogens that are involved in the regulation of endometrial cell proliferation, differentiation and apoptosis. Indeed, during the menstrual cycle the mitogenic effects of estrogen, balanced by the differentiating properties of progesterone, are mediated by the IGF system. In the primate, the major sites of synthesis of IGFBP-1 and IGFBP-2 are the liver and decidualized gestational endometrium, and the central nervous system, respectively.

During the menstrual cycle IGFBP-1 is a minor secretory product of the endometrial epithelium and stroma, how- 
ever its production is markedly induced by progesterone during the late luteal phase [1-6]. Indeed, during pregnancy IGFBP-1 becomes the major soluble protein synthesised and secreted by the primate decidual cell $[4,7$ 10]. Endometrial IGFBP-2 synthesis also increases during the luteal phase and pregnancy [6] and, similarly, appears to be induced by progesterone within human endometrial stromal cells $[11,12]$.

Clinical studies have shown that plasma levels of IGFBP1 are rapidly downregulated in response to insulin administration [13-15]. Furthermore, work on the rat has demonstrated a differential level of induction of hepatic IGFBP-1 and IGFBP-2 synthesis by insulin deficiency [16]. This in vivo regulation of IGFBP-1 and IGFBP-2 by insulin has been confirmed by in vitro studies in the rat [17] and human [11,18-20]. Studies of the liver IGFBP-1 proximal promoter region have revealed an insulin response sequence adjacent to the glucocorticoid response element, and analysis of these DNA sequences has demonstrated insulin inhibition and glucocorticoid or progesterone stimulation of IGFBP-1 transcription [21-25].

The earlier studies of the differential inhibitory effects of insulin on IGFBP-1 and IGFBP-2 gene expression $[11,16]$ prompted us to examine this further in the primate, using the baboon as a model. The objective of this study, therefore, was to examine the effect of insulin on protein synthesis, secretion and mRNA steady state levels of IGFBP-1 and IGFBP-2 in the baboon endometrium in vitro.

\section{Methods \\ Tissue samples}

Baboon endometrial specimens were obtained from animals either on day 10 post-ovulation $(n=3)$, following ovariectomy $(\mathrm{n}=3)$ and subsequent treatment with steroids (estradiol plus progesterone; [26]), between days 25 and 30 of pregnancy $(n=1)$ [27], or on days 24 or 25 postovulation $(\mathrm{n}=2)$, following long-term treatment with steroids [28]. Steroids (Sigma-Aldrich, St. Louis, USA) were administered via $6 \mathrm{~cm}$ silastic implants using one of the following regimens: either 14 days of estradiol, 14 days of estradiol followed by 14 days of estradiol plus progesterone, or 14 days of estradiol followed by 14 days of progesterone [26]. The Animal Care Committee of the University of Illinois approved all of these experimental procedures.

\section{Explant culture}

Tissue explants $(n=2)$ of endometrium from the different treatment groups of baboons were cultured in serum-free MEM devoid of insulin (Gibco/BRL, Gaithersburg, USA) over $48 \mathrm{~h}$, controlling for differences in explant weight as described previously [29]. Explants were cultured in the presence or absence of $1.5 \mu \mathrm{M}$ insulin (Sigma-Aldrich, St.
Louis, USA). Some of the baboon explants were also cultured in the presence of the following hormones: estradiol (36 $\mathrm{nM})$, progesterone $(1 \mu \mathrm{M})$ and hCG (Profasi; EMD Serono, Rockland, USA; $0.5 \mathrm{IU} / \mu \mathrm{l})$. The concentration of insulin in the complete medium was within physiological levels [30] whilst the concentrations of estradiol, progesterone and hCG were comparable to those assayed in conditioned media from the explant culture of day 25 pregnant baboon placentae [27]. Explant-conditioned media was harvested and dialysed against $2 \mathrm{mM}$ Tris/ $\mathrm{HCl}$ ( $\mathrm{pH} 8.2$ ) to remove the salt and amino acids that would otherwise interfere with gel electrophoresis and western blotting, and was replaced with a fresh basal medium at 20-24 h intervals over a short-term culture period of two days. Protein was quantified following dialysis using the Lowry method. Equal amounts of protein $(50 \mu \mathrm{g})$ from the conditioned media were lyophylised and dissolved in Laemmli buffer for gel electrophoresis. At the termination of the culture period, the tissue was immediately rapidly frozen at $-70^{\circ} \mathrm{C}$ for RNA or protein extraction.

\section{SDS-PAGE, western blotting and immunoassay}

Conditioned media from the explant cultures was separated by one-dimensional gradient (5-17\%) SDS-PAGE (20-200 $\mu \mathrm{l} /$ lane) under reducing conditions, employing molecular weight markers, as described previously [7]. Protein loading was checked using Ponceau stain, as described previously [29]. Gels were stained for $1 \mathrm{~h}$, shaking at room temperature, with $0.1 \%$ (wt/vol) Coomassie brilliant blue in $50 \%(\mathrm{vol} / \mathrm{vol})$ methanol and destained prior to western blotting.

Proteins were transferred from the gels to nitrocellulose membranes by electroblotting, as described previously [5]. Western blots of the conditioned media harvested from the explant cultures were first probed with a polyclonal antibody to IGFBP-2 (UBI, Lake Placid, USA) at a titre of 1:2000, the immunoreactivity being visualized using alkaline phosphatase. Using the same membranes, they were then probed with a monoclonal antibody $\left(\mathrm{B}_{2} \mathrm{H}_{10}\right)$ to IGFBP-1 [10,31] at a titre of 1:2000, the immunoreactivity being visualized using an enhanced chemiluminescence kit (Amersham, Arlington Heights, USA). The results from some blots were semi-quantified using densitometry $[6,32]$.

Immunoreactive IGFBP-1 in explant culture medium was assayed using a specific immunoradiometric assay kit (DSL, Webster, USA). Assays were performed in triplicate.

\section{Extraction of RNA and northern blotting}

Total RNA was extracted from the tissue explants following short-term (two days) culture using TRI reagent (Molecular Research Center Inc., Cincinnati, USA). The concentration and purity of RNA was estimated using 
$268 / 28 \mathrm{~nm}$ ratios on a spectrophotometer. This RNA (20 $\mu \mathrm{g})$ was then separated on a $1.2 \%$ agarose-formaldehyde gel and transferred to nitrocellulose. These northern blots were hybridised at high stringency with $32 \mathrm{P}$-labelled cDNA probes (1.2 Kp and $795 \mathrm{bp}$, respectively) to human IGFBP-1 [10] and IGFBP-2 [33].

\section{Results \\ Effects of insulin on IGFBP-I and IGFBP-2 production}

In the baboon explant cultures it was found that, generally, IGFBP-1 and IGFBP-2 production was progesteronedependent. However, the synthesis of IGFBP-1 was inversely proportional to the level of insulin in the culture medium whereas that of IGFBP-2 was directly proportional to it.

Western blotting of conditioned medium harvested from explants of endometrium collected from two baboons at day 10 post-ovulation demonstrates the effect that the presence or absence of insulin in the culture medium has on the production of IGFBP-1 and IGFBP-2 (Figure 1). For IGFBP-1, two bands can be seen at around $32 \mathrm{kD}$ and 19 $\mathrm{kD}$, the latter representing a proteolytic fragment [6,32]. Levels of IGFBP-1 are virtually undetectable in the presence of insulin whereas they are clearly evident in the absence of insulin, levels freshly released on day two of culture being approximately double those on day one (Figure 1A). Assay of these media samples for immunoreactive IGFBP-1 confirms the western blotting data but does show that IGFBP-1 is produced in varying amounts by different explants in the absence of insulin (Figure 1C). In contrast, IGFBP-2 is detectable whether insulin is present or absent, levels being higher in the presence of insulin, but not changing markedly from day one to day two of culture (Figure 1B).

Western blotting of conditioned medium harvested from explants of endometrium collected from steroid-treated ovariectomized baboons demonstrates that the production of both IGFBP-1 and IGFBP-2 is induced by progesterone, and augmented by estradiol (Figure 2). Again however, levels of IGFBP-1 are virtually undetectable in the presence of insulin whereas they are clearly evident in the absence of insulin (Figure 2A). Assay of these media samples for immunoreactive IGFBP-1 confirms the western blotting data and shows the synergistic effect that estradiol and progesterone have in vivo, particularly when amplified by the absence of insulin (Figure 2C). Again, levels of IGFBP-2 are higher in the presence of insulin (Figure 2B).

Western blotting of conditioned medium harvested from explants of endometrium (collected from intact, longterm steroid-treated ovariectomized baboons) exposed to steroids and hCG in the culture medium demonstrates that the production of IGFBP-1 is enhanced, but only in the absence of insulin (Figure 3A). Again, higher levels of IGFBP-1 were observed on the second day of culture (Figure 3A), levels of IGFBP-2 being less variable, except in the absence of insulin where lower levels of IGFBP-2 were detectable on the second day of culture (Figure 3C). Furthermore, exposure to hCG appeared to inhibit steroidinduced synthesis and secretion of IGFBP-1 in the absence of insulin (Figures 3A and 3B).

Western blotting of conditioned medium harvested from explants of endometrium (either implantation site or non-implantation site tissue) collected from two baboons at day 32 of pregnancy, demonstrates the effect that the presence or absence of insulin in the culture medium has on the production of IGFBP-1 (Figure 4A) and IGFBP-2 (Figure $4 \mathrm{~B}$ ) is both modulated by pregnancy and is regionalized. In tissue from pregnant animals IGFBP-1 production is evident even in the presence of insulin, the inhibitory effect of insulin being less pronounced in tissue taken from the implantation site, where decidualization has begun (Figure 4A). Assay of these media samples for immunoreactive IGFBP-1 confirms the western blotting data (Figure 4C). Furthermore, a clear inverse doseresponse relationship between the concentration of insulin in the culture medium and the production of IGFBP-1 from non-implantation site tissue can be seen (Figure 5), and this effect appears to be enhanced after two days of culture. Again, IGFBP-2 production is decreased in the absence of insulin, but only in tissue taken from the nonimplantation site (Figure 4B).

\section{Effects of insulin on IGFBP-I and IGFBP-2 expression}

Northern blot analysis of endometrial RNA extracted from explant tissue (collected from a day 30 pregnant baboon) cultured with or without insulin and other hormones over a two-day period confirms that the production of IGFBP1 and IGFBP-2 under these conditions is determined by their expression (Figures 3B \&3D). Message for IGFBP-1 is only evident in the absence of insulin, the level of message being increased in tissue exposed to steroids and hCG (Figure 3B). Indeed, following a two-day culture of endometrial explant tissue a clear inverse dose-response relationship between the concentration of insulin in the culture medium and with the level of message for IGFBP1 can be seen (Figure 5B). In contrast, message for IGFBP2 is present both in the absence and in the presence of insulin, and the level of message appears to be increased in tissue that has been exposed to insulin (Figures $3 \mathrm{D}$ \&5C).

\section{Discussion}

To our knowledge, this is the first full report that characterizes the differential regulation of IGFBP-1 and IGFBP-2 by insulin in the baboon endometrium. We were able to 


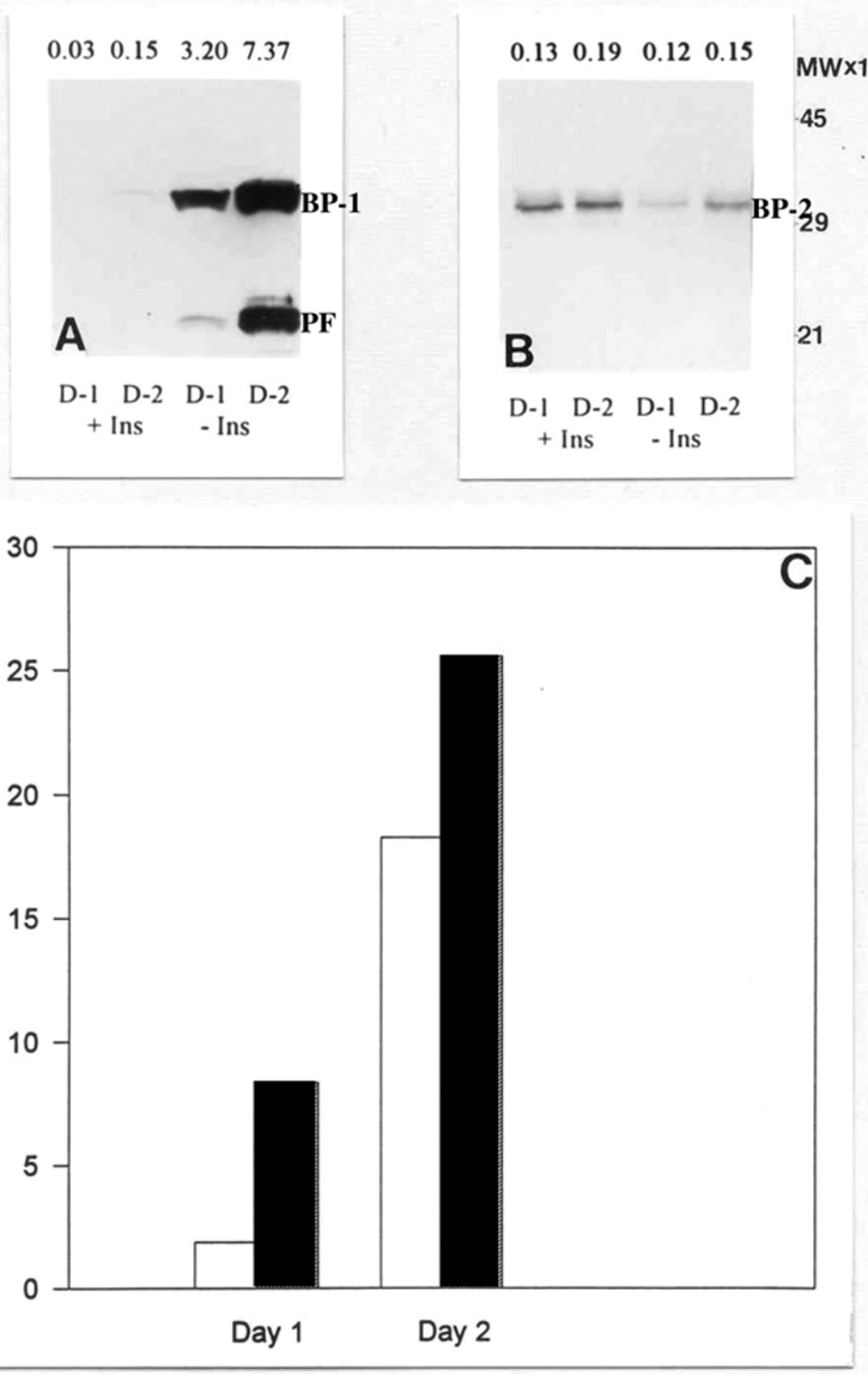

\section{Figure I}

Effect of insulin on IGFBP-I and IGFBP-2 at day 10 post-ovulation. The effect of insulin (+/- Ins) on IGFBP-I (BP-I) and IGFBP-2 (BP-2) secretion in culture media taken from endometrial explants $(n=2)$ at day 10 post-ovulation. Media samples were analysed after $24 \mathrm{~h}(\mathrm{D}-\mathrm{I})$ and $48 \mathrm{~h}(\mathrm{D}-2)$ incubation by western blotting for IGFBP-I (A) and IGFBP-2 (B), and by ELISA for IGFBP-I (C). Values above each band in A and B represent their optical density. PF: Proteolytic fragment of IGFBP-I. Open and closed bars in $C$ represent IGFBP-I levels released by explants from two different animals in the absence of insulin. 
$\begin{array}{llllll}0.00 & 0.00 & 0.00 & 0.82 & 0.00 & 0.11\end{array}$

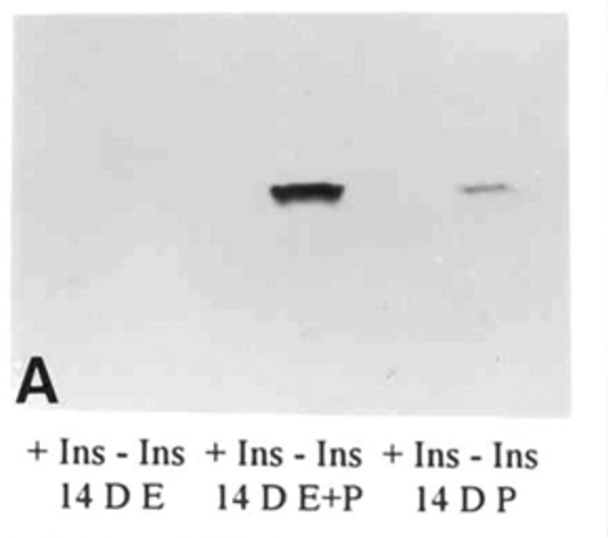

$\begin{array}{llllll}0.00 & 0.00 & 1.13 & 0.93 & 0.21 & 0.12\end{array}$

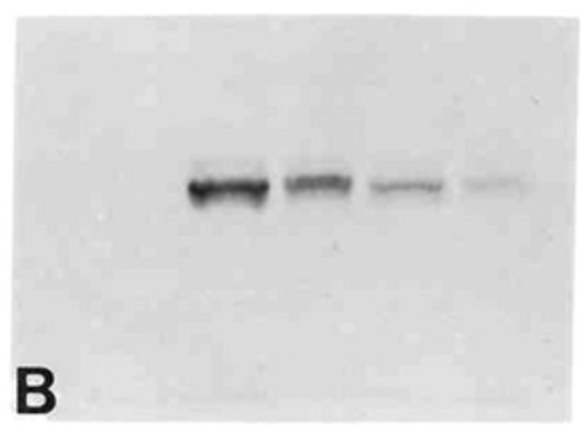

+ Ins - Ins + Ins - Ins + Ins - Ins $14 \mathrm{DE} \quad 14 \mathrm{DE}+\mathrm{P} \quad 14 \mathrm{D} \mathrm{P}$

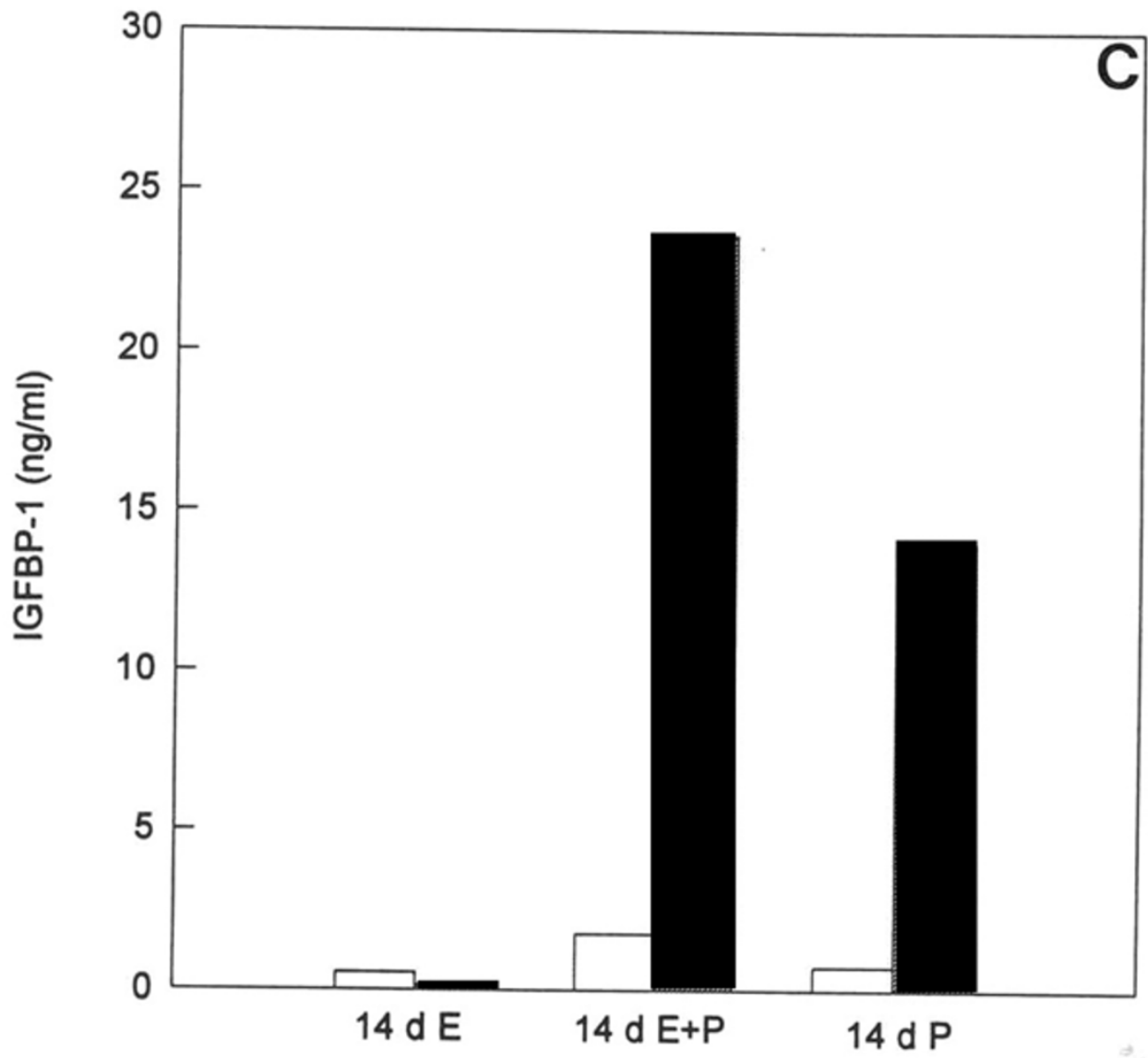

\section{Figure 2}

Effect of insulin (+/- Ins) on IGFBP-I and IGFBP-2 secretion in steroid-treated ovariectomized baboons.

Endometrial explants $(n=3)$ were obtained following steroid treatment and incubated in vitro. Media samples were analysed by western blotting for IGFBP-I (A) and IGFBP-2 (B), and by ELISA for IGFBP-I (C) after $24 \mathrm{~h}$ incubation. $14 \mathrm{~d}$ E: Treatment with estradiol for 14 days; $14 \mathrm{~d} \mathrm{E}+\mathrm{P}$ : Treatment with estradiol for 14 days followed by treatment with estradiol plus progesterone for 14 days; $14 \mathrm{~d}$ P: Treatment with estradiol for 14 days followed by treatment with progesterone alone for 14 days.

These treatments represent the late follicular, mid secretory and late secretory stages of the cycle, respectively. Values above each band in A and B represent their optical density. Open bars: + Insulin; Closed bars: - Insulin. 


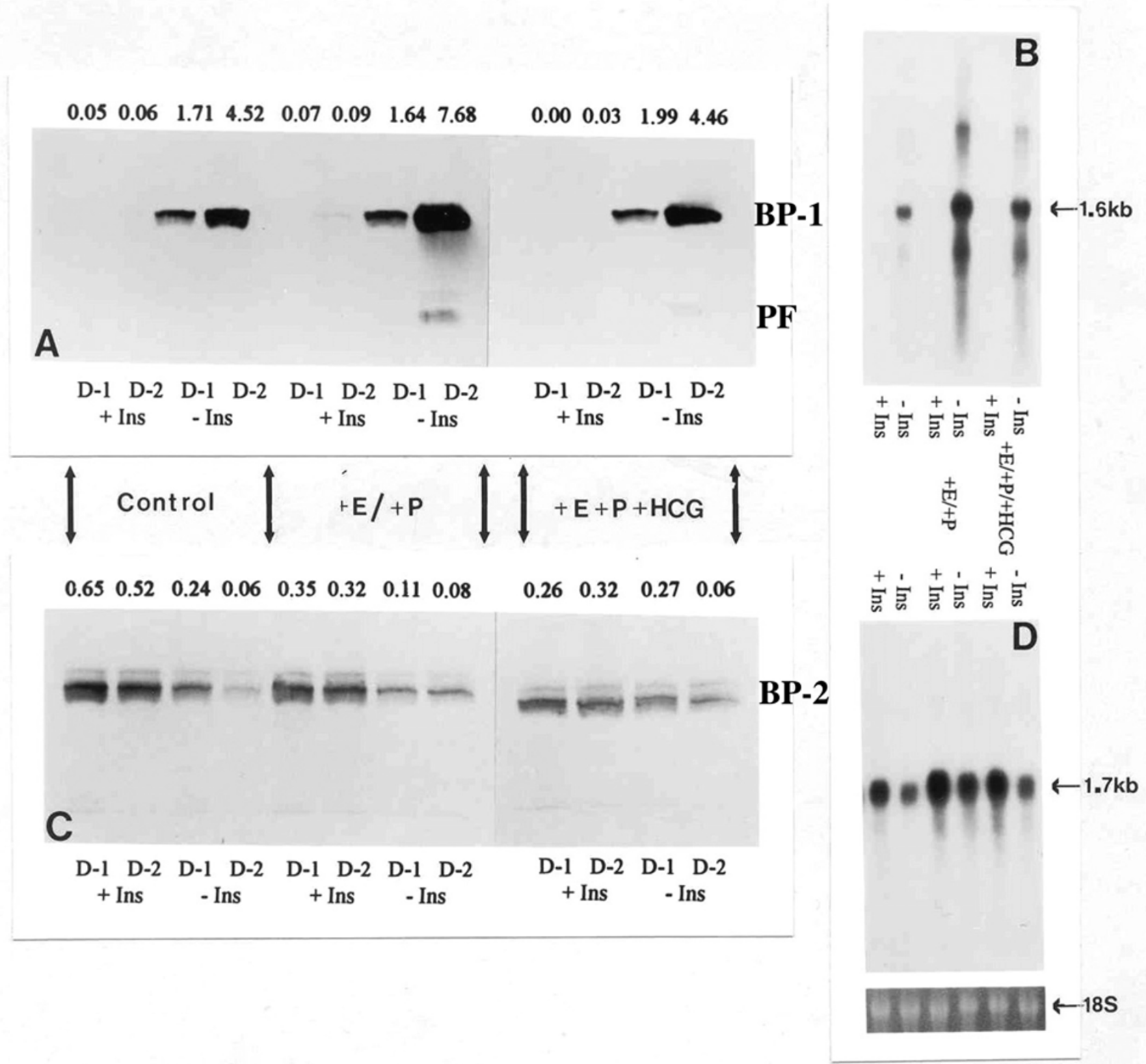

\section{Figure 3}

Effect of insulin and hormones on IGFBP-I and IGFBP-2 during simulated pregnancy. The effect of insulin (+/- Ins) and hormones (hCG and/or estradiol and progesterone) on IGFBP-I (BP-I) and IGFBP-2 (BP-2) synthesis in culture media taken from endometrial explants of intact baboons treated long-term (day 24-25) with steroids to simulate pregnancy $(n=2)$. Media and tissue samples were analysed by western and northern blotting for IGFBP-I (A \& B) and IGFBP-2 (C \& D), respectively, after $24 \mathrm{~h}(\mathrm{D}-\mathrm{I})$ and $48 \mathrm{~h}$ (D-2) incubation. Values above each band in A and B represent their optical density. PF: Proteolytic fragment of IGFBP-I; E: Estradiol; P: Progesterone.

demonstrate that physiological concentrations of insulin can inhibit IGFBP-1 production and mRNA expression in a time- and dose-dependent manner in vitro. As illustrated in Figure 5, insulin at a dose range from $0.09 \mu \mathrm{M}$ to 1.5 $\mu \mathrm{M}$ resulted in decreasing levels of immunoreactive protein and mRNA for IGFBP-1. In contrast, the synthesis of
IGFBP-2 was stimulated in the presence of insulin, although this increase was not statistically significant. Conversely, in the absence of insulin, we observed induction of the in vitro synthesis of IGFBP-1 in tissues exhibiting low levels of de novo synthesis. Vice versa, the synthesis of IGFBP-2 was inhibited in the absence of insulin. 

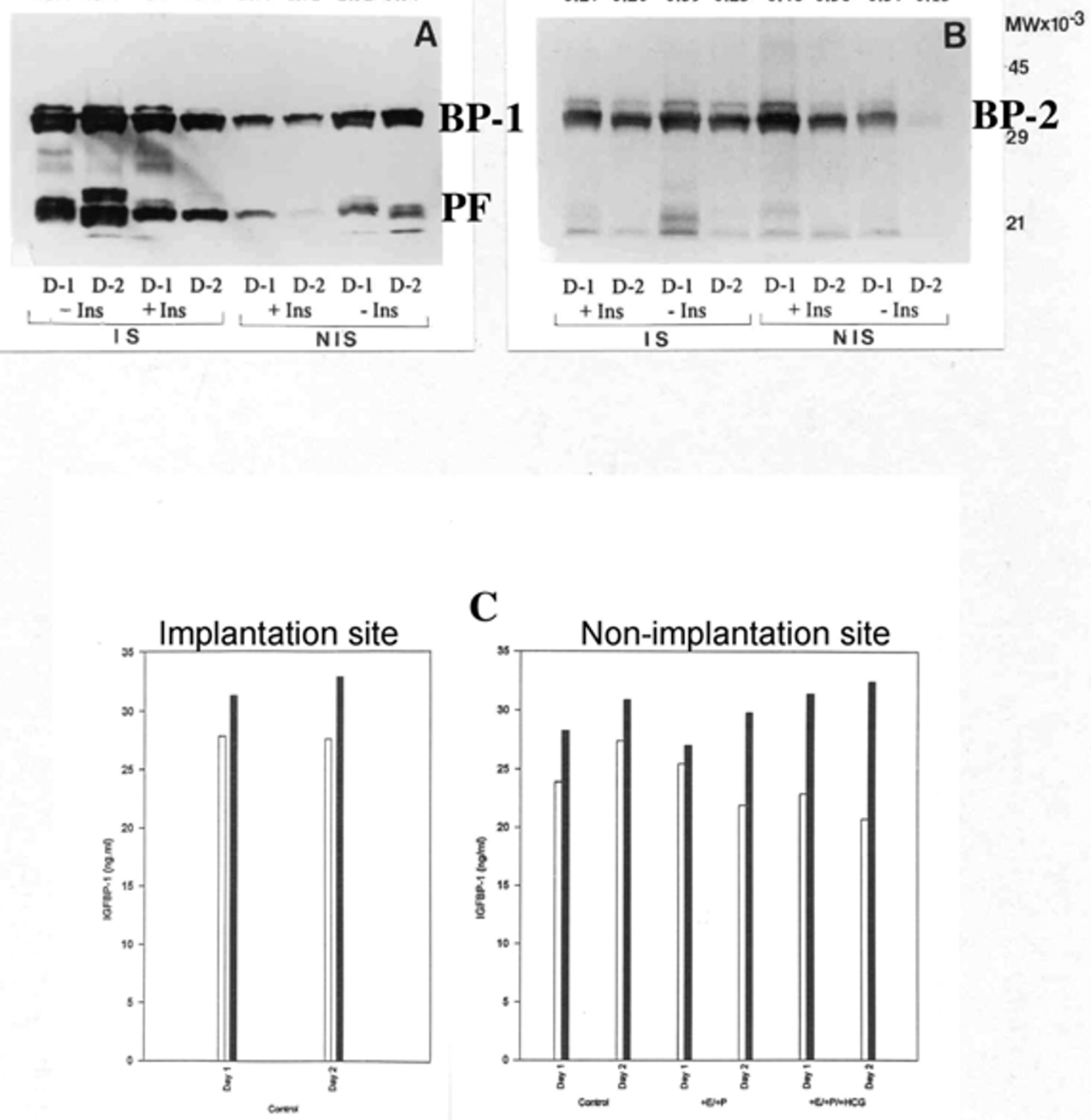

\section{Figure 4}

Effect of insulin on IGFBP-I and IGFBP-2 at the implantation and non-implantation sites. The effect of insulin (+/Ins) on IGFBP-I (BP-I) and IGFBP-2 (BP-2) secretion in culture media taken from endometrial explants of the implantation and non-implantation sites of a day 32 pregnant baboon $(n=I)$. Media samples were analysed by western blotting for IGFBP-I (A) and IGFBP-2 (B), and by ELISA for IGFBP-I (C) after $24 \mathrm{~h}$ (D-I) and $48 \mathrm{~h}(\mathrm{D}-2)$ incubation. Values above each band in A and B represent their optical density. PF: Proteolytic fragment of IGFBP-I. Open bars: + Insulin; Closed bars: - Insulin. 


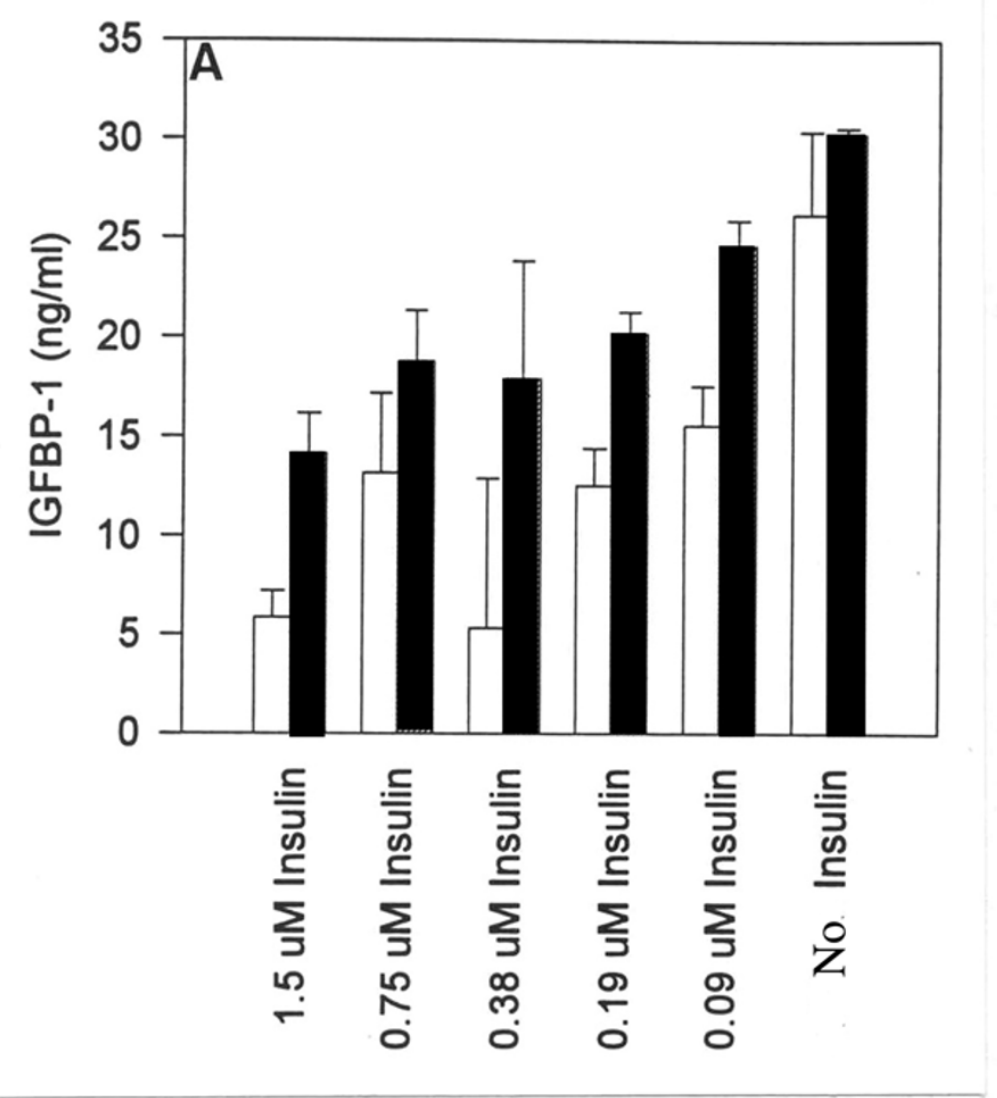

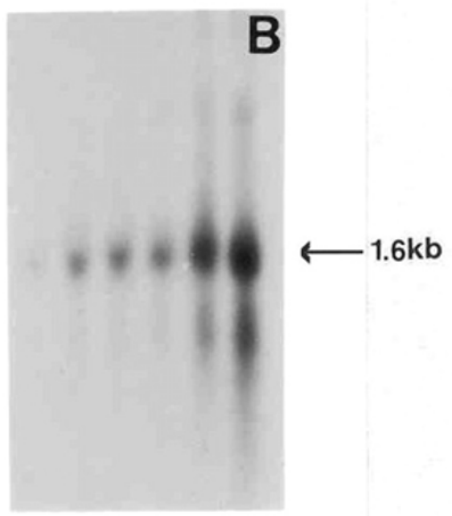
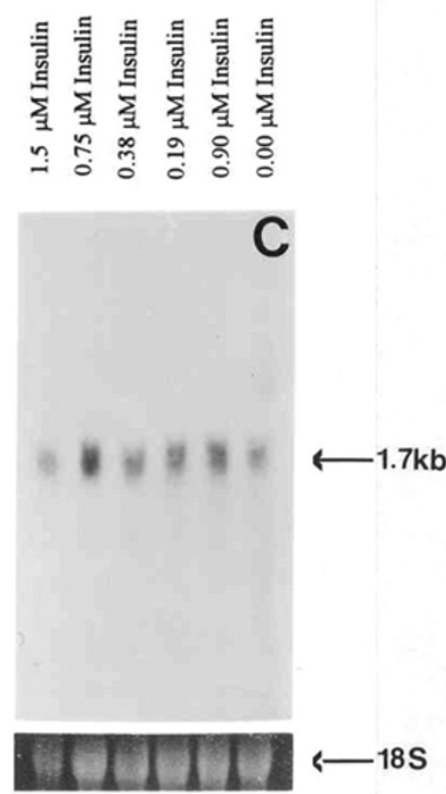

\section{Figure 5}

Dose-response effect of insulin on IGFBP-I in non-implantation endometrium at day 25 of pregnancy. The doseresponse effect of insulin on immunoreactive levels of IGFBP-I in culture media taken from endometrial explants $(n=2)$ of the non-implantation site of a day 25 pregnant baboon. Media and tissue samples were analysed by ELISA for IGFBP-I (A) after 24 $\mathrm{h}$ (Open bars) and $48 \mathrm{~h}$ (Closed bars) incubation, and by northern blotting, respectively, for IGFBP-I (B) and IGFBP-2 (C).

Of particular interest is the relationship between the differentiation of endometrial stromal cells to decidual cells, whereby the endometrium of the menstrual cycle becomes the decidua of pregnancy, and the change in sensitivity of these tissues to insulin. Although insulin produced inhibitory effects on IGFBP-1 synthesis in midluteal and progesterone-treated baboon tissues, similar to those observed with explants from pregnant baboons, baseline secretory levels of IGFBP-1 were nevertheless lower than those seen in pregnancy. This demonstrates that the inhibitory effects of insulin on IGFBP-1 synthesis are evident prior to decidualization (when decidual cells begin their synthesis of IGFBP-1). Interestingly, in the baboon the inhibitory effects of insulin are more evident in non-pregnant tissue, or in pregnant tissue away from the implantation site. This suggests that when decidual synthesis of IGFBP-1 is initiated locally, during the establishment of pregnancy, the effects of insulin become less 
apparent. Hence, potential paracrine regulatory factors that influence IGFBP-1 synthesis may be induced and secreted during pregnancy.

IGFBP-1 is the major secretory product of the decidualized endometrium and in situ expression of IGFBP-1 mRNA is most abundant in those decidual cells adjacent to the invading extravillous trophoblast (EVT), which in contrast expresses IGF-II mRNA [34]. IGFBP-1 and IGFBP-2 possess an RGD sequence that can bind to RGD binding sites on cell surface integrins such as the integrin, $\alpha_{5} \beta_{1}$ (also a receptor for fibronectin), and RGD- $\alpha_{5} \beta_{1}$ binding is essential for the stimulation of trophoblast migration [35-38]. Indeed, it has been suggested that IGFBP-1 and IGF-II can stabilize each other at the EVT cell surface, potentially exerting a synergistic effect upon EVT cell migration and invasion [36,37]. Therefore, our observation in this study that the inhibitory effect of insulin upon IGFBP-1 secretion is diminished at the implantation site in the baboon endometrium may have physiological relevance.

Insulin could conceivably play an important role in the regulation of IGFBP-1 secretion, decidualization and implantation. In this respect, it has been found that insulin can inhibit IGFBP-1 secretion and gene expression in human endometrial stromal cells $[11,39]$. It has also been shown that cytotrophoblasts plated onto decidual multilayers are unable to penetrate the stromal cells unless decidual IGFBP-1 production is inhibited by insulin [40]. This impedence of trophoblast migration appears to be mediated by RGD- $\alpha_{5} \beta_{1}$ binding since the permissive effect of insulin may be reversed with exogenous IGFBP-1 but not with IGFBP-3, which does not possess an RGD sequence [40]. Also, it appears that the actions of IGFBP1 and IGF-II are further regulated by hCG [41-44]. Our observation of apparent inhibition of steroid-induced IGFBP-1 synthesis and secretion by hCG in the absence of insulin is consistent with this, and suggests a mechanism whereby embryo-derived hCG may conceivably augment implantation via increased receptivity and angiogenesis within the endometrium.

The corresponding changes in the levels of immunoreactivity and mRNA for IGFBP-1 and IGFBP-2 observed in this study indicate that regulation by insulin may occur at the level of transcription. Hence, changes in production of IGFBP-1 and IGFBP-2 in response to insulin presumably may reflect changes in the abundance of their mRNAs. Therefore, transcriptional or post-transcriptional regulation of IGFBP-1 and IGFBP-2 mRNA abundance may be crucial to the regulation of IGFs within the endometrium. In this respect, insulin may co-ordinate the bioactivity of IGFs with nutritional status through the regulation of IGFBPs. If so, such a mechanism could be important in the regulation of trophoblast invasion during implanta- tion, perhaps particularly so in pathological states such as intra-uterine growth restriction. The inhibition of endometrial IGFBP-1 expression by insulin seen in this study correlates with other studies that have identified an insulin response sequence in the IGFBP-1 promoter, and similar phenomena have been observed in other in vitro systems [17-19,45]. Down-regulation of IGFBP-1 gene expression by insulin appears to be a phosphatidylinositol 3-kinase (PI3 kinase) dependent mechanism [46]. One potential pathway downstream of PI3 kinase that has been proposed to regulate IGFBP-1 mRNA levels involves activation of protein kinase B/Akt [47]. Through this pathway, Akt-dependent phosphorylation of two forkhead transcription factors (Foxo1 and Foxo3) has been shown to directly inhibit their binding to the insulin response element in the promoter of the IGFBP-1 gene via their nuclear exclusion [48-53]. An alternative pathway downstream of PI3 kinase, independent of Foxo1 and Foxo3 modulation, has also been proposed to regulate IGFBP-1 gene transcription in response to insulin [54,55]. This pathway involves the mammalian target of rapamycin, a protein with a catalytic domain homologous to that of PI3 kinase.

\section{Conclusion}

In conclusion, to our knowledge this is the first full report that confirms in the baboon endometrium the central role that insulin has in the regulation of IGFBP synthesis, as reported by others in different experimental models. As such, this work further demonstrates the value of the baboon as an experimental model for the human in our understanding of the events surrounding decidualization, implantation and pregnancy.

\section{Authors' contributions}

ATF and SCB were responsible for the conception, design, funding and supervision of this work and SDF was responsible for writing the manuscript. ATF and SCB read and approved the final manuscript.

\section{Acknowledgements}

We thank Elizabeth Allen, Jillian Ashmore, Kathleen Donnelly and Juliet Jackson for their excellent technical assistance. This work was supported by grants from the NIH HD 42280 (to ATF) and MRC (to SCB).

\section{References}

I. Wahlström T, Seppälä M: Placental protein I 2 (PP I 2) is induced in the endometrium by progesterone. Fertility and Sterility 1984, 4I:78I-784.

2. Bell S, Patel S, Kirwan P, Drife J: Protein synthesis and secretion by the human endometrium during the menstrual cycle and the effect of progesterone in vitro. Journal of Reproduction and Fertility 1986, 77:221-231.

3. Rutanen E-M, Koistinen R, Sjoberg J, Julkunen M, Wahlstrom T, Bohn $H$, Seppala M: Synthesis of placental protein 12 by human endometrium. Endocrinology 1986, I I 8: 1067-107I.

4. Fazleabas A, Verhage $H$, Waites G, Bell S: Characterization of an insulin-like growth factor binding protein (IGF-BP), analogous to human pregnancy-associated secreted endometrial 
$\alpha$ l-globulin ( $\alpha$ I-PEG) in decidua of the baboon (Papio anubis) placenta. Biology of Reproduction 1989, 40:873-885.

5. Bell S, Jackson J, Ashmore J, Zhu H, Tseng L: Regulation of insulinlike growth factor-binding protein-I synthesis and secretion by progestin and relaxin in long term cultures of human endometrial stromal cells. Journal of Clinical Endocrinology and Metabolism I991, 72: I014-1024.

6. Tarantino S, Verhage H, Fazleabas A: Regulation of insulin-like growth factor binding proteins in the baboon (Papio anubis) uterus during early pregnancy. Endocrinology 1992 130:2354-2362.

7. Bell S, Hales M, Patel S, Kirwan P, Drife J: Protein synthesis and secretion by the human endometrium and decidua during early pregnancy. British Journal of Obstetrics and Gynaecology 1985 , 92:793-803.

8. Bell S, Patel S, Hales M, Kirwan P, Drife J: Immunochemical identification and characterization of pregnancy-associated endometrial $\alpha \mathrm{I}$ - and $\alpha 2$-globulins secreted by the human endometrium and decidua. Journal of Reproduction and Fertility 1985, 74:26I-270.

9. Rutanen E-M, Koistinen R, Wahlstrom T, Bohn H, Ranta T, Seppala M: Synthesis of placental protein $I 2$ by human decidua. Endocrinology 1985, I 16:1304-1309.

10. Fazleabas A, Jaffe R, Verhage H, Waites G, Bell S: An insulin-like growth factor-binding protein in the baboon (Papio anubis) endometrium: synthesis, immunocytochemical localisation, and hormonal regulation. Endocrinology 1989, 124:232I-2329.

II. Fleming S, Allen L, Wood P, McKendrick L, Ashmore G, Jackson J, Bell S: Switch between $34 \mathrm{kDa}$ and $29 \mathrm{kDa}$ IGF binding protein (IGFBP-2 and-I) production during and after in vitro differentiation of human endometrial stromal cells to decidual cells and effect of progestagen and insulin. Journal of Reproduction and Fertility Abstract Series 1991, 8:28.

12. Giudice L, Milkowski D, Lamson G, Rosenfeld R, Irwin J: Insulin-like growth factor binding proteins (IGFBP-2 and IGFBP-3) in human endometrium: steroid-dependent messenger RNA expression and protein synthesis. Journal of Clinical Endocrinology and Metabolism 199I, 72:779-787.

13. Brismar K, Gutniak M, Povoa G, Werner S, Hall K: Insulin regulates the $35 \mathrm{kDa}$ IGF binding protein in patients with diabetes mellitus. Journal of Endocrinological Investigation 1988, I 1:599-602.

14. Holly J, Biddlecombe R, Dunger D, Edge J, Amiel S, Howell R, Chard $T$, Rees L, Wass J: Circadian variation of $\mathbf{G H}$-independent IGFbinding protein in diabetes mellitus and its relationship to insulin. A new role for insulin? Clinical Endocrinology 1988, 29:667-675.

15. Suikkari A-M, Koivisto V, Rutanen E-M, Yki-Jarvinen H, Karonen S-L, Seppala M: Insulin regulates the serum levels of low molecular weight insulin-like growth factor-binding protein. Journal of Clinical Endocrinology and Metabolism 1988, 66:266-273.

16. Ooi G, Orlowski C, Brown A, Becker R, Unterman T, Rechler M: Different tissue distribution and hormonal regulation of messenger RNAs encoding rat insulin-like growth factor-binding proteins-I and -2. Molecular Endocrinology 1990, 4:32I-328.

17. Unterman T, Oehler D, Murphy L, Lacson R: Multihormonal regulation of insulin-like growth factor-binding protein- $I$ in rat H4IIE hepatoma cells: the dominant role of insulin. Endocrinology | $99 \mid$, I 28:2693-270|.

18. Conover C, Liu F, Powell D, Rosenfeld R, Hintz R: Insulin-like growth factor binding proteins from cultured human fibroblasts. Characterization and hormonal regulation. Journal of Clinical Investigation 1989, 83:852-859.

19. Lewitt M, Baxter R: Regulation of growth hormone-independent insulin-like growth factor-binding protein (BP-28) in cultured human fetal liver explants. Journal of Clinical Endocrinology and Metabolism 1989, 69:246-252.

20. Singh A, Hamilton-Fairley D, Koistinen R, Seppala M, James V, Franks $S$, Reed M: Effect of insulin-like growth factor-type I (IGF-I) and insulin on the secretion of sex hormone binding globulin and IGF-I binding protein (IBP-I) by human hepatoma cells. Journal of Endocrinology 1990, I24:RI-R3.

21. Unterman TG, Lacson RG, McGary E, Whalen C, Purple C, Goswami RG: Cloning of the rat insulin-like growth factor binding protein-I gene and analysis of its 5 ' promoter region. Biochemical and Biophysical Research Communications 1992, I85:993-999.
22. Suwanickul A, Morris SL, Powell DR: Identification of an insulinresponsive element in the promoter of the human gene for insulin-like growth factor binding protein- I. The Journal of Biological Chemistry 1993, 268: I7063-17068.

23. Goswami R, Lacson R, Yang E, Sam R, Unterman T: Functional analysis of glucocorticoid and insulin response sequences in the rat insulin-like growth factor-binding protein-I promoter. Endocrinology 1994, 134:736-743.

24. Robertson DG, Marino EM, Thule PM, Seneviratne CK, Murphy LJ: Insulin and glucocorticoids regulate IGFBP-I expression via a common promoter region. Biochemical and Biophysical Research Communications 1994, 200:226-232.

25. Suwanichkul A, Allander SV, Morris SL, Powell DR: Glucocorticoids and insulin regulate expression of the human gene for insulin-like growth factor-binding protein-I through proximal promoter elements. The Journal of Biological Chemistry 1994, 269:30835-3084I.

26. Fazleabas AT, Miller JB, Verhage HG: Synthesis and release of estrogen- and progesterone-dependent proteins by the baboon (Papio anubis) uterine endometrium. Biology of Reproduction 1988, 39:729-736.

27. Fazleabas A, Donnelly KM, Mavrogianis PA, Verhage HG: Secretory and morphological changes in the baboon (papio anubis) uterus and placenta during pregnancy. Biology of Reproduction 1993, 49:695-704.

28. Hild-Petito S, Donnelly KM, Miller JB, Verhage HG, Fazleabas A: A baboon (Papio anubis) simulated pregnant model: cell specific expression of insulin-like growth factor binding-proteinI (IGFBP-I), type I IGF receptor (IGF-I R) and retinol binding protein (RBP) in the uterus. Endocrine 1995, 3:639-65 I.

29. Fazleabas A, Verhage $\mathrm{H}$ : Synthesis and release of polypeptides by the baboon (Papio anubis) uterine endometrium in culture. Biology of Reproduction 1987, 37:979-988.

30. Kemnitz JW, Sapolsky RM, Altmann J, Muruthi P, Mott GE, Stefanick ML: Effects of food availability on serum insulin and lipid concentrations in free-ranging baboons. American Journal of Primatology 2002, 57:13-19.

31. Bell S, James R, Jackson J, Patel S, Waites G, Walczak K: Monoclonal antibodies to human secretory "pregnancy-associated endometrial $\alpha$-I globulin," an insulin-like growth factor binding protein: characterization and use in radioimmunoassay, western blotting and immunohistochemistry. American Journa of Reproductive Immunology and Microbiology 1989, 20:87-96.

32. Fazleabas AT, Donnelly KM: Characterization of insulin-like growth factor binding proteins by two-dimensional polyacrylamide gel electrophoresis and ligand blot analysis. Analytical Biochemistry 1992, 202:40-45.

33. Binkert C, Landwehr J, Mary J-L, Schwander J, Heinrich G: Cloning, sequence analysis and expression of a cDNA encoding a novel insulin-like growth factor binding protein (IGFBP-2). EMBO Journal 1989, 8:2497-2502.

34. Han VKM, Bassett N, Walton J, Challis JRG: The expression of insulin-like growth-factor (IGF) and IGF-binding protein (IGFBP) genes in the human placenta and membranes: evidence for IGF-IGFBP interactions at the materno-fetal interface. Journal of Clinical Endocrinology and Metabolism 1996, $81: 2680-2693$.

35. Jones JI, Gockerman A, Busby WH Jr, Wright G, Clemmons DR: Insulin-like growth factor binding protein I stimulates cell migration and binds to the alpha 5 beta $I$ integrin by means of its Arg-Gly-Asp sequence. Proceedings of the National Academy of Sciences of the United States of America 1993, 90: 10553-10557.

36. Irving JA, Lala PK: Functional role of cell surface integrins on human trophoblast cell migration: regulation by TGF-beta, IGF-II, and IGFBP-I. Experimental Cell Research 1995, 217:419-427

37. Hamilton GS, Lysiak J], Han VK, Lala PK: Autocrine-paracrine regulation of human trophoblast invasiveness by insulin-like growth factor (IGF)-II and IGF-binding protein (IGFBP)-I. Experimental Cell Research 1998, 244:147-156.

38. Gleeson LM, Chakraborty C, McKinnon T, Lala PK: Insulin-like growth factor-binding protein I stimulates human trophoblast migration by signaling through alpha 5 beta I integrin via mitogen-activated protein Kinase pathway. Journal of Clinical Endocrinology and Metabolism 200I, 86:2484-2493. 
39. Giudice LC, Dsupin BA, Irwin JC: Steroid and peptide regulation of insulin-like growth factor binding-proteins secreted by human endometrial stromal cells is dependent on stromal differentition. Journal of Clinical Endocrinology and Metabolism 1992, 75:|235-|24|.

40. Irwin JC, Giudice LC: Insulin-like growth factor binding proteinI binds to placental cytotrophoblast alpha5betal integrin and inhibits cytotrophoblast invasion into decidualized endometrial stromal cultures. Growth Hormone IGF Research |998, 8:2I-3I.

41. Licht P, Russu V, Lehmeyer S, Moll J, Siebzehnrubl E, Wildt L: Intrauterine microdialysis reveals cycle-dependent regulation of endometrial insulin-like growth factor binding protein-I secretion by human chorionic gonadotropin. Fertility and Sterility 2002, 78:252-258.

42. Licht $P$, Fluhr $H$, Neuwinger J, Wallwiener $D$, Wildt L: Is human chorionic gonadotropin directly involved in the regulation of human implantation? Molecular and Cellular Endocrinology 2007, 269:85-92.

43. Jasinska A, Han V, Fazleabas AT, Kim JJ: Induction of insulin-like growth factor binding protein-I expression in baboon endometrial stromal cells by cells of trophoblast origin. Journal of the Society for Gynecological Investigation 2004, I I:399-405.

44. Zygmunt M, McKinnon T, Herr F, Lala PK, Han VK: HCG increases trophoblast migration in vitro via the insulin-like growth factor-II/mannose-6 phosphate receptor. Molecular Human Reproduction 2005, II:26I-267.

45. Conover C, Lee P: Insulin regulation of IGF binding protein production in cultured $\mathrm{HepG}_{2}$ cells. Journal of Clinical Endocrinology and Metabolism 1990, 70:1062-1067.

46. Band CJ, Posner BI: Phosphatidylinositol 3'-kinase and p70s6k are required for insulin but not bisperoxovanadium 1,10 phenanthroline (bpV(phen)) inhibition of insulin-like growth factor binding protein gene expression. Evidence for MEKindependent activation of mitogen-activated protein kinase by bpV(phen). The Journal of Biological Chemistry 1997, 272: I38-I45.

47. Cichy SB, Uddin S, Danilkovich A, Guo S, Klippel A, Unterman TG: Protein kinase B/Akt mediates effects of insulin on hepatic insulin-like growth factor-binding protein-I gene expression through a conserved insulin response sequence. The Journal of Biological Chemistry 1998, 273:6482-6487.

48. Brunet A, Bonni A, Zigmond MJ, Lin MZ, Juo P, Hu LS, Anderson MJ, Arden KC, Blenis J, Greenberg ME: Akt promotes cell survival by phosphorylating and inhibiting a Forkhead transcription factor. Cell 1999, 96:857-868.

49. Durham SK, Suwanichkul A, Scheimann AO, Yee D, Jackson JG, Barr FG, Powell DR: FKHR binds the insulin response element in the insulin-like growth factor binding protein-I promoter. Endocrinology 1999, I 40:3| 140-3 | 46.

50. Guo S, Rena G, Cichy S, He X, Cohen P, Unterman T: Phosphorylation of serine 256 by protein kinase $B$ disrupts transactivation by FKHR and mediates effects of insulin on insulin-like growth factor-binding protein-I promoter activity through a conserved insulin response sequence. The Journal of Biological Chemistry 1999, 274:17184-17192.

5I. Hall RK, Yamasaki T, Kucera T, Waltner-Law M, O'Brien R, Granner DK: Regulation of phosphoenolpyruvate carboxykinase and insulin-like growth factor-binding protein-I gene expression by insulin. The role of winged helix/forkhead proteins. The Journal of Biological Chemistry 2000, 275:30169-30175.

52. Brownawell AM, Kops G], Macara IG, Burgering BM: Inhibition of nuclear import by protein kinase B (Akt) regulates the subcellular distribution and activity of the forkhead transcription factor AFX. Molecular and Cellular Biology 200I, 2I:3534-3546.

53. Rena G, Prescott AR, Guo S, Cohen P, Unterman TG: Roles of the forkhead in rhabdomyosarcoma (FKHR) phosphorylation sites in regulating | 4-3-3 binding, transactivation and nuclear targetting. The Biochemical Journal 200I, 354:605-6I2.

54. Patel S, Lochhead PA, Rena G, Fumagalli S, Pende M, Kozma SC, Thomas $G$, Sutherland C: Insulin regulation of insulin-like growth factor-binding protein-I gene expression is dependent on the mammalian target of rapamycin, but independent of ribosomal S6 kinase activity. The Journal of Biological Chemistry 2002, 277:9889-9895.

55. Mounier C, Dumas $\mathrm{V}$, Posner BI: Regulation of hepatic insulinlike growth factor-binding protein-I gene expression by insu- lin: central role for mammalian target of rapamycin independent of forkhead box $O$ proteins. Endocrinology 2006, 147:2383-239|.
Publish with Biomed Central and every scientist can read your work free of charge

"BioMed Central will be the most significant development for disseminating the results of biomedical research in our lifetime. "

Sir Paul Nurse, Cancer Research UK

Your research papers will be:

- available free of charge to the entire biomedical community

- peer reviewed and published immediately upon acceptance

- cited in PubMed and archived on PubMed Central

- yours - you keep the copyright

Submit your manuscript here:

http://www.biomedcentral.com/info/publishing_adv.asp 